Digital Press Life Sciences

The Effect of Different Methods of Giving Probiotic Lactobacillus salivarius I-11 on Broilers Performance in Starter Period

Sri Sumarsih, Bambang Sulistiyanto and and Cahya Setya Utama

10th Asian Conference of Lactic Acid Bacteria

I Nengah Sujaya, Endang S. Rahayu, Tyas Utami (eds) 


\title{
The Effect of Different Methods of Giving Probiotic Lactobacillus salivarius I-11 on Broilers Performance in Starter Period
}

\author{
Sri Sumarsih*, Bambang Sulistiyanto, and Cahya Setya Utama \\ Faculty of Animal Agricultural, Diponegoro University, Semarang \\ *e-mail: ssumarsih71@gmail.com
}

\begin{abstract}
The aim of the research was to study the effect of different methods of giving probiotics Lactobacillus salivarius I-11 on broilers' performance in the starter period. A total of 200 days old chick were reared until 14 days of age. The research was used a completely randomized design with four treatments and five replications. The treatments were $\mathrm{T} 0=$ Control with no probiotics, $\mathrm{T} 1=$ Probiotics with Forcefeeding, $\mathrm{T} 2$ = Probiotics in Feed, $\mathrm{T} 3=$ Probiotics in drinking Water. The parameters were broilers performance (feed conversion ratio /FCR, bodyweight gain/ BWG and feed consumption / FC,) in the starter period with different methods of giving probiotics. The data were analyzed by ANOVA and DMRT tests. The Result showed that The FCR of $(\mathrm{T} 1, \mathrm{~T} 2$ dan T3) were lower $(\mathrm{p}<0.05)$ but the BWG of broilers were higher $(\mathrm{p}<0.05)$ compared to control treatment. There are no significant results on the FC of T0 with T1, T2 and T3. The conclusion was the Broilers in starter period without given probiotics showed the worse performance compared to broilers with probiotics Lactobacillus salivarius I-11.
\end{abstract}

\section{Keywords}

force-feeding, probiotics, lactobacillus salivarius I-11., broilers, performance

\section{Introduction}

Increasing broilers production can be achieved by giving feed additives in the form of probiotics to replace antibiotics. Lactobacillus $s p$ is a species of lactic acid bacteria probiotic that have useful effects on poultry health. Lactobacillus can be reduced colonization of pathogenic bacteria and support host performance [1,2]. Probiotics supplementation can improve the feed conversion ratio of chicken [3]. In poultry production, probiotics do not leave residues in the animal products, improve nutrient utilization and increase productivity [4]. There are some methods for giving probiotics that are force-feeding, giving in the feed and drinking water. The aim of the research was to study the effect of different methods of giving probiotics Lactobacillus salivarius I-11 on broilers performance in the starter period.

\section{Materials and Methods}

The research was done on, Animal and Agricultural Sciences Faculty, Laboratory Feed Technology Diponegoro University. Two hundred day old chick (DOC) strain Cobb unsex, isolate Lactobacillus salivarius I-11. and complete feed. The complete feed contains crude protein $20 \%$ and Metabolism energy 3000 $\mathrm{MJ} / \mathrm{Kg}$.

Two hundred broilers divided into 4 groups with 4 treatments, 5 replications and 10 units. Maintenance of broilers started with disinfection and fumigation cage space. For one day, DOC was given sugar water. In group T1, Lactobacillus Sp was given by $1 \mathrm{ml}$ each day of $10^{9} \mathrm{cfu} / \mathrm{ml}$. One group of DOC (T2) was given by $2 \%$ Lactobacillus Sp on feed and T3 Groups were given by $2 \%$ Lactobacillus Sp on drinking water. Maintenance of broilers for 15 days.

The research used a completely randomized design with four treatments and five replications. The treatments were $\mathrm{T} 0=$ Control with no probiotics, $\mathrm{T} 1=$ Probiotics with Force-feeding, $\mathrm{T} 2=$ Probiotics in 
Feed, T3 = Probiotics in drinking Water. The parameters were broilers performance (feed conversion ratio /FCR, body weight gain/ BWG and feed consumption / FC. The data were analyzed by ANOVA (analyzed variance) and DMRT (Duncan's Multiple Range Tests performed) to know the difference between treatments [5].

\section{Results And Discussion}

The effect of different methods of giving probiotics Lactobacillus Sp. on broilers performance in the starter period showed in Table 1.

Table 1 Average of WG, FC and FCR Broilers in starter period with different methods of giving probiotics Lactobacillus salivarius I-11

\begin{tabular}{|c|c|c|c|}
\hline Treatments & $\begin{array}{c}\text { WG } \\
\text { (g/chicken/ } \\
\text { week) }\end{array}$ & $\begin{array}{c}\mathrm{FC} \\
\text { (g/chicken/ } \\
\text { week) }\end{array}$ & FCR \\
\hline Control & $345.53 \pm 3.1^{b}$ & $465.52 \pm 3.2$ & $1.35 \pm 3.4 \mathrm{~b}$ \\
\hline Force feeding & $362.81 \pm 3.1^{\mathrm{a}}$ & $464.56 \pm 3.2$ & $1.28 \pm 3.4^{a}$ \\
\hline Probiotics in feed & $364.41 \pm 3.1^{\mathrm{a}}$ & $464.21 \pm 3.2$ & $1.27 \pm 3.4^{a}$ \\
\hline $\begin{array}{l}\text { Probiotics in drinking } \\
\text { water }\end{array}$ & $363.22 \pm 3.1^{\mathrm{a}}$ & $464.33 \pm 3.2$ & $1.28 \pm 3.4$ \\
\hline
\end{tabular}

Note: Different superscripts showed significant $(\mathrm{p}<0.05)$ differences among treatmens

The ANOVA showed that Lactobacillus salivarius I-11. as probiotics by force-feeding, in feed and drinking water affects the BWG broilers were significantly $(\mathrm{p}<0.05)$ increased but FC were significantly $(\mathrm{p}<0.05)$ decreased. The results are agreement with the findings of Mirnejad et al. who reported refinement in body weight gain by Probiotics [6]. The probiotics stimulate the immunity of the chickens in two ways (a) antigen released by the dead organisms are absorbed and thus stimulate the immune system or (b) probiotic migrate throughout the gut wall and multiply to a limited extent [7]. It is believed that there is some relationship between the immune system with the performance [8]. There is no significantly different effect of control treatments (without probiotics) and broilers with probiotics caused by the same quality feed. Some studies show that probiotics in feed no effect on feed consumption $[9,10]$.

\section{Conclusion}

The conclusion was the Broilers in starter period without given probiotics showed the worse performance compared to broilers with probiotics Lactobacillus salivarius I-11.

\section{References}

1. Ergun, A., S. Yalcin and P. Sacakli. 2000. The usage of probiotic and zinc bacitracin in broiler rations. Ankara Universitesi Veteriner Fakultesi Dergisi, 47: 271-280

2. Gordon T. D. 2002. Intestinal health through dietary fiber, prebiotics and probiotics, Food Technol. 56(4): 23-28.

3. Hamid, A., Z.F. Khan, A. Munid and M.A. Qadeer. 1994. Probiotics in poultry production. Bangl. J. Sci. Ind. Res., 29: 1-12

4. Havenaar, R. and S. Spanhaak. 1994. Probiotics from an immunological point of view. Curr. Opin. Biotechnol., 5: 320-325 
5. Kabir, S.M.L., M.M. Rahman, M. B. Rahman. 2004. The dynamics of probiotics on growth performance and immune response in broilers. International Journal of Poultry Science 3(5) : 361-364

6. Mirnejad R, H. Jafar, A. Ardebilli, H. Babavalia. 2010. Reduction of enterotoxigenic Escherichia coli colonization by the oral administration of Lactobacillus casei as a probiotic in a murine model. Afr. J. Microbiol. Res. 4(21): 2283-2287.

7. Panda, A.K., M.R. Reddy, S.V.R. Rao, M.V.L.N. Raju and N. K. Praharaj. 2000. Growth, carcass characteristics, immunocompetence and response to Escherichia coli of broilers fed diets with various levels of probiotic. Archiv fur Geflugelkunde., 64: 152-156.

8. Steel, R. G. D. and J. H. Torrie. 1981. Principles and Procedures of Statistic. McGrow Hill Book Co. Inc., New York

9. Villena, J; M. Medina, E. Vintinfii. 2008. Stimulation of respiratory immunity by oral administration of Lactobacillus lactis. Can J. Mirobiol 54 (8) : $630-638$

10. Wills, W. L., O. S. Isikhuemhen, S. Ibrahim, K. King, R. Minor and E. I. Ohimain. 2010. Effect of Dietary fungus Mycellated grain on broiler performance and enteric colonization with bifidobacteria and Salmonella. Int. J. of Poult. Sci. 9 (1) : 48 - 52 